\title{
From Charcot's descriptions to the current understanding of neuropsychiatric symptoms in multiple sclerosis
}

\author{
Das descrições de Charcot à compreensão atual dos sintomas neuropsiquiátricos na \\ esclerose múltipla \\ Carlos B. TAUIL'1,2, Felipe VON GLEHN³', Raimundo NONATO-RODRIGUES ${ }^{1}$, Jaqueline R.A.A. GOMES ${ }^{4}$, \\ Carlos O. BRANDÃOB , Leonilda M.B. dos SANTOS ${ }^{3}$, Leopoldo L. dos SANTOS-NETO'
}

\begin{abstract}
Neuropsychiatric disorders in multiple sclerosis have been known since the original clinicopathological description by Charcot in the late nineteenth century. Charcot, in the last decades of his life, became involved in the field of neuropsychiatry. This produced a battle between rival schools in the era that still echoes to this day. Charcot's intuition, including the line of thought of Babinski, one of his most famous disciples, was that there was a connection between mood disorders and many of the diseases of the nervous system. Medicine's concern with establishing a relationship between mood disorders and disease stems from the ancient and middle ages with references found in the Hippocratic doctrine. However, it was only in the second half of the nineteenth and early twentieth century, with Charcot's discoveries, that this discussion was established in a structured way, laying the foundations of neuropsychiatry.
\end{abstract}

Keywords: Neuropsychiatry; multiple sclerosis; neurology, history.

\section{RESUMO}

Os distúrbios neuropsiquiátricos na esclerose múltipla são conhecidos desde a descrição clínico-patológica original de Charcot no final do século XIX. Charcot nas últimas décadas de sua vida se envolveu no campo da neuropsiquiatria. Isso produziu uma batalha de escolas rivais na época que ainda ecoa até hoje. A intuição de Charcot, incluindo a linha de pensamento de Babinski, um de seus discípulos mais famosos, foi a teoria correta da conexão entre os transtornos do humor e muitas das doenças do sistema nervoso. A preocupação da Medicina em estabelecer uma relação entre transtornos do humor e doenças vem das idades antiga e média, com referências encontradas na doutrina hipocrática. No entanto, foi apenas na segunda metade do século XIX e início do século XX que, com as descobertas de Charcot essa discussão foi realizada de maneira estruturada, estabelecendo os fundamentos da neuropsiquiatria.

Palavras-chave: Neuropsiquiatria; esclerose múltipla; neurologia, história.

Like other autoimmune diseases, the pathophysiology of multiple sclerosis (MS) involves a complex interaction between genetic and environmental factors ${ }^{1}$. However, psychological stressors and states of anxiety and depression also seem to contribute to the onset of clinical and subclinical relapses in $\mathrm{MS}^{2}$.

Psychiatric symptoms in MS are heterogeneous and associated with central nervous system (CNS) abnormalities.
These symptoms result from the interaction of the individual's organ and tissue changes influenced by immune system activation, not only a "state of the soul", or solely the result of CNS inflammation, but a product of the complex interaction between various biological systems ${ }^{3}$. Neuropsychiatric disorders in MS have been known about since the original clinical pathological description by Charcot in the late nineteenth

\footnotetext{
${ }^{1}$ Universidade de Brasília, Departamento de Ciências Médicas, Brasília DF, Brasil.

${ }^{2}$ Universidade Católica de Brasília, Departamento de Medicina, Brasília DF, Brasil.

${ }^{3}$ Universidade de Campinas, Departamento de Neuroimunologia, Campinas SP, Brasil.

${ }^{4}$ Hospital de Base, Brasília DF, Brasil.
}

Carlos B. Tauil (iD) https://orcid.org/0000-0003-1137-2398; Felipe Von Glehn (iD https://orcid.org/0000-0002-1004-7641; Raimundo Nonato-Rodrigues (iD) https://orcid.org/0000-0002-1119-9807; Jacqueline R. A. A. Gomes (iD https://orcid.org/0000-0002-7243-4073; Carlos 0. Brandão iD https://orcid.org/0000-0002-4898-5916; Leonilda M. B. dos Santos iD https://orcid.org/0000-0002-3600-9205; Leopoldo L. dos Santos-Neto iD https://orcid.org/0000-0002-8060-6111

Correspondence: Carlos B. Tauil; Universidade de Brasília - UnB; SHIN QL 14 CJ 7 CS 14; 71535-275 Brasília DF, Brasil; E-mail: cbtauil@gmail.com Conflict of interest: There is no conflict of interest to declare

Received 20 August 2018; Received in final form 29 September 2018; Accepted 11 December 2018. 
century ${ }^{4}$. These symptoms can be divided into two major groups: cognitive and behavioral disorders; and affective and mood disorders. The second group includes depression, fatigue, sleep disorders, bipolar-like disorders, euphoria, excessive crying, pathological laughter, and anxiety.

Previous studies have shown that MS patients present with depression significantly more often than other patients with chronic diseases, especially young men ${ }^{5}$. However, although these symptoms are common, they are often underdiagnosed, causing suffering and worsening of the patient's quality of life. It is estimated, for example, that one-third of patients with MS and major depression or suicidal ideation receive no treatment for their mood $\operatorname{disorder}^{6,7}$ (Figure1) ${ }^{8}$.

\section{Charcot and Babinski}

Murray, in his book on the history of multiple sclerosis, described that the earliest systematized and original descriptions of MS were well defined by Jean-Martin Charcot, a neurologist at Hôpital de Salpêtrière in 1868, as "sclérose en plaques". The three most reliable indicators of multiple sclerosis-intention tremor, nystagmus, and scanning speech-became known as the Charcot triad ${ }^{10}$. The analysis in this study at the time, of the first reports of patients with MS, pointed to elements of marked relgiosity, mysticism, histrionic behavior and even cases of selfmutilation, already demonstrating an intimate relationship between MS and neuropsychiatry ${ }^{11}$. Mood and emotion disorders in MS were reported by Charcot in his compiled Leçons sur les maladies du système nerveux: Faites a la Salpêtrière (Lessons on Nervous System Diseases: at the Salpêtrière), published in $1868^{4}$.
This work, a compilation of classes given by Charcot at Salpêtrière Hospital, exposed his ideology that was undoubtedly influenced by the precepts of Claude Bernard (1813-1878). Charcot believed that the description of diseases should be structured beyond Hippocratic clinical observation, trying to correlate this with knowledge of pathology and experimental medicine ${ }^{12}$. His studies demonstrated a solid scientific rigor that led to Charcot obtaining the position of Chair for Diseases of the Nervous System in 1882, as well as assuring his incontestable leadership of several brilliant pupils and their peers. Charcot's strict but unifying personality resulted in a fundamental set of clinical and pathological descriptions that are the basis of modern neurology ${ }^{13}$. However, Charcot's restless investigative spirit was not satisfied, and in the last decades of his life, he became involved in the complex field of hysteria and hypnosis ${ }^{14}$. This produced a battle between rival schools in the era that echoes to this day. Charcot's intuition, including the line of thought of Babinski, one of his most famous disciples, led to his hypothesis of a bidirectional connection between psychiatric or mood disorders and many of the diseases of the nervous system ${ }^{14}$.

\section{Studies beyond the twentieth century}

In 1883, Julius Wagner-Jauregg described the case of a woman with psychotic hallucinations, who had a high fever due to a skin infection, but when the infectious process resolved, the psychotic symptoms disappeared ${ }^{15}$. Wagner-Jauregg spent the next decades of his career trying to replicate what he had observed and, by 1917, had some success in treating patients who had psychosis due to tertiary syphilis with blood from soldiers with malaria (Figure $2^{16}$ ).

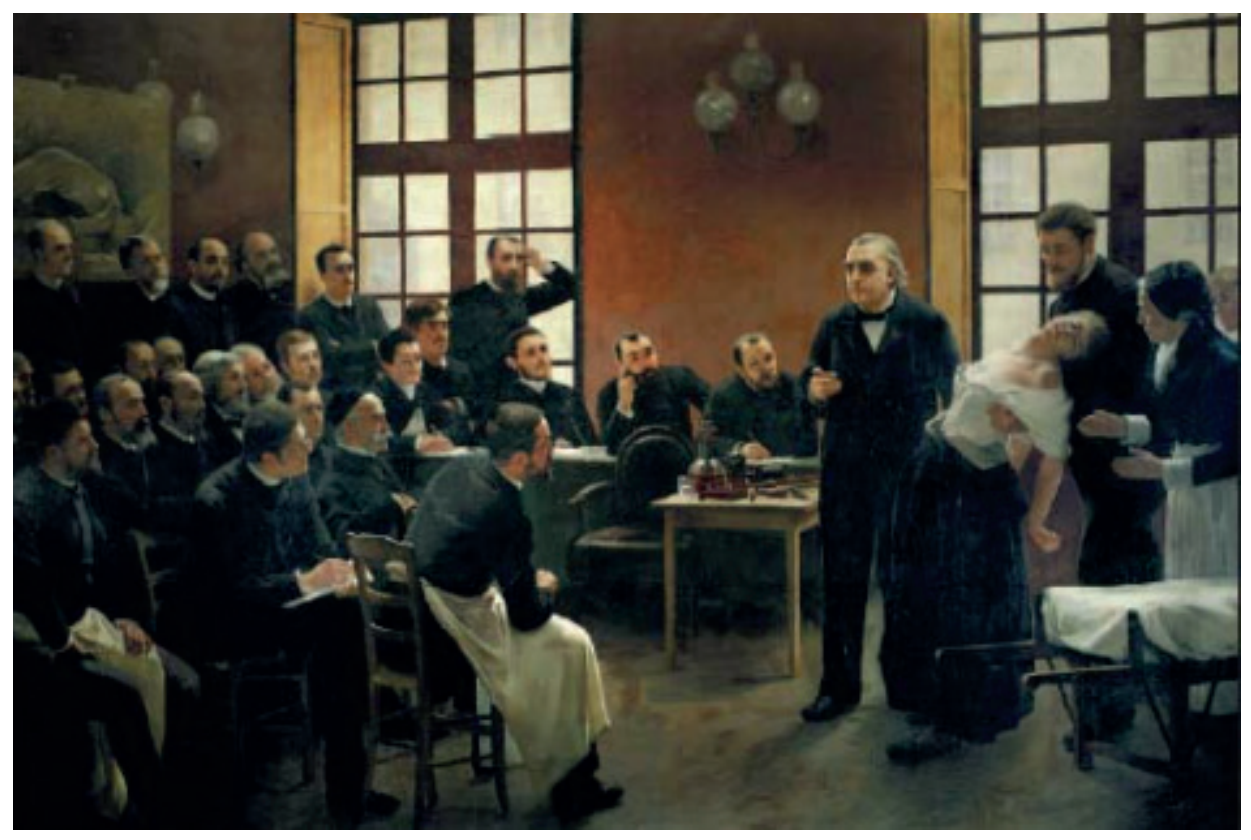

Figure 1. Charcot teaching about hysteria in Salpêtrière Hospital, Paris. 


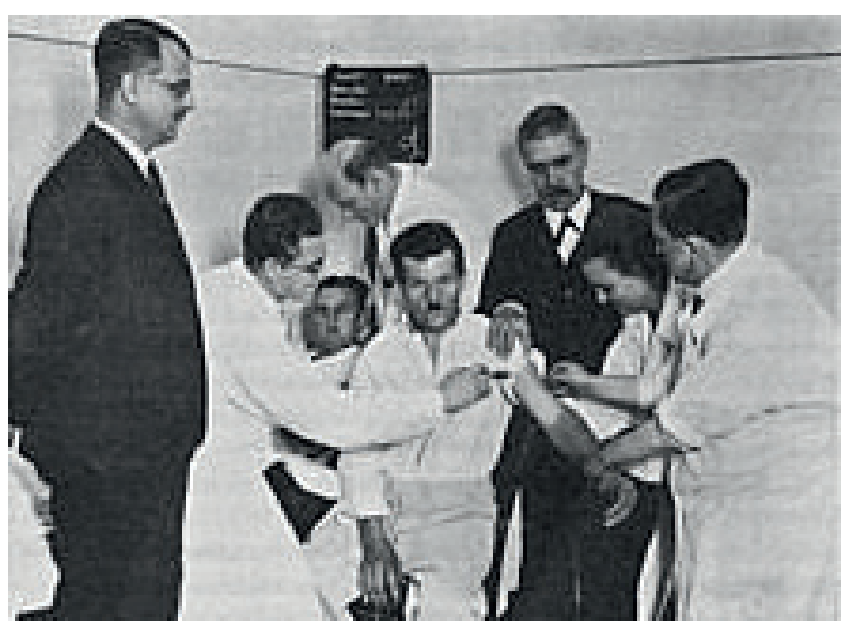

Figure 2. Wagner-Jauregg and the theory of malariotherapy ${ }^{16}$.

This treatment, known as malariotherapy, was used in thousands of patients between the 1920s and 1930s and accorded Wagner-Jauregg the Nobel Prize in Medicine in $1927^{15}$.

Among others, there was an original description of MS associated with depression made by Wilhelm Nero Pilate Barbellion, the pseudonym of Bruce Frederick Cummings, who reported on his life with a chronic neurological disease in his Journal of a Disappointed Man ${ }^{14}$.

The first series of cases describing the association between mood disorders and MS was published as a structured paper similar to contemporaneous ones in 1926. In this study, Cottrell and Wilson reported a case series analyzing the relationship between affective symptoms and $\mathrm{MS}^{17}$.

In the early 1990s, a relationship of the immune system with depression, as proposed by Smith ${ }^{18}$, and Kwidzinski and Bechmann ${ }^{19}$, suggested that proinflammatory cytokines, such as IL-1, activate the corticotropin-releasing factor of the hypothalamus, inducing hyperactivation of the hypothalamic-pituitary-adrenal axis and the symptoms of depression.

\section{Final considerations}

In recent decades, the relationship between neuropsychiatry and neuroimmunology has intensified as scientific findings have revealed consistent evidence of the influence of mood disorders on diseases in general, and on MS in particular ${ }^{20}$.

Medicine's concern with establishing a relationship between temperament, personality, mood disorders, and disease stems from the ancient and middle ages, with references found in the texts by Hippocrates and Galen ${ }^{12}$. However, it was only in the second half of the nineteenth and early twentieth century, with Charcot's pioneering studies, that this discussion was established in a structured way, laying the foundations for neuropsychiatry ${ }^{14}$. In the period between the world wars, clinical observations of the relationship between the immunological reaction and its influence on psychiatric diseases were reported by Wagner-Jauregg, and malariotherapy was developed $^{15}$. Cottrell and Wilson published one of the first papers demonstrating the epidemiological relationship between mood disorders and $\mathrm{MS}^{17}$.

With our current knowledge of neuroimmunology, especially concerning studies of MS and autoimmune encephalitis, we can find scientific confirmation of the epidemiological and molecular aspects of the intimate relationship between mood disorders and behavior, and immune system activity explaining, in a consistent and scientifically rigorous manner, the hypotheses made over a century ago by Charcot and his disciples ${ }^{21,22}$.

\section{References}

1. Mancuso R, Hernis A, Agostini S, Rovaris M, Caputo D, Fuchs D, et al. Indoleamine 2,3 dioxygenase (IDO) expression and activity in relapsing-remitting multiple sclerosis. PLoS One. 2015 Jun;10(6):e0130715. https://doi.org/10.1371/journal.pone.0130715

2. Rossi S, Studer V, Motta C, Polidoro S, Perugini J, Macchiarulo $G$, et al. Neuroinflammation drives anxiety and depression in relapsing-remitting multiple sclerosis. Neurology. 2017 Sep;89(13):1338-47. Available from: http://ovidsp.ovid.com/ovidweb. cgihttps://doi.org/10.1212/WNL.0000000000004411

3. Boeira MV, Berni GA, Passos IC, Kauer-Sant'Anna M, Kapczinski F. Virginia Woolf, neuroprogression, and bipolar disorder. Br J Psychiatry. 2017 Jan-Mar;39(1):69-71. https://doi.org/10.1590/1516-4446-2016-1962

4. Charcot JM. Leçons sur les maladies du système nerveux: faites a la Salpêtrière. Paris;1877. Vol II: Sclerose en plaques, 293-294.

5. Simpson S Jr, Tan H, Otahal P, Taylor B, Ponsonby AL, Lucas RM, et al. Anxiety, depression and fatigue at 5-year review following CNS demyelination. Acta Neurol Scand. 2016 Dec;134(6):403-13. https://doi.org/10.1111/ane.12554

6. Fragoso YD, Frota ER, Lopes JS, Noal JS, Giacomo MC, Gomes S, et al. Severe depression, suicide attempts, and ideation during the use of interferon beta by patients with multiple sclerosis [serial online]. Clin Neuropharmacol. 2010 Nov-Dec;33(6):312-6. https://doi.org/10.1097/WNF.0b013e3181f8d513

7. World Health Organization - WHO. Projections of mortality and causes of death, 2015 and 2030. Geneva: World Health Organization; 2013.

8. Broillet PA. Painting. Une leçon clinique sur l'hysterie a la Salpêtrière: Image mod. Scale. 1887 [cited 2018 June 22] Availablefrom:https://pt.wikipedia.org/wiki/Charcot_La Salpêtrière

9. Murray TJ. Multiple sclerosis: the history of a disease. New York: Demos Medical; 2005. Chapter 4: The steps toward a discovery: the early medical reports; p. 61-95.

10. Murray TJ. Multiple sclerosis: the history of a disease. New York: Demos Medical; 2005.Chapter 5: The building blocks of discovery; p. 95-103.

11. Murray TJ. Multiple sclerosis: the history of a disease. New York Demos Medical; 2005.Chapter 6: The Contribuition of J.M.Charcot 1868; p.103-39.

12. Finger S. Origins of Neuroscience : a history of explorations into brain function. Oxford: Oxford University Press; 1994. 
13. Lyons AS, Petrucelli RJ. Medicine an illustrated history. New York: Harry N. Abrams.; 1987.

14. Bogousslavsky J. Following Charcot: a forgotten history of neurology and psychiatry. Basel: Karger; 2011. (Frontiers of Neurology and Neuroscience; Vol. 29).

15. Wetsman N. Inflammatory illness: why the next wave of antidepressants may target the immune system. Nat Med. 2017 Sep;23(9):1009-11. https://doi.org/10.1038/nm0917-1009

16. Vogel, G. Malaria as Lifesaving Therapy. Science. 2013 Nov;342(6159):686. https://doi.org/10.1126/science.342.6159.686

17. Cottrell SS, Wilson SA. The affective symptomatology of dissaminated sclerosis: a study of 100 cases. J Neurol Psychopathol. 1926 Jul;7(25):1-30. https://doi.org/10.1136/jnnp.s1-7.25.1

18. Smith RS. The macrophage theory of depression. Med Hypotheses. 1991 Aug;35(4):298-306. https://doi.org/10.1016/0306-9877(91)90272-Z
19. Kwidzinski E, Bechmann I. IDO expression in the brain: a double-edged sword. J Mol Med (Berl). 2007 Dec;85(12):1351-9. https://doi.org/10.1007/s00109-007-0229-7

20. Murphy R, O'Donoghue S, Counihan T, McDonald C, Calabresi PA, Ahmed M A S, et al. Neuropsychiatric syndromes of multiple sclerosis. J Neurol Neurosurg Psychiatry. 2017 Aug;88(8):697-708. https://doi.org/10.1136/jnnp-2016-315367

21. Dalmau J, Graus F. Antibody-Mediated Encephalitis. N Engl J Med. 2018 Mar;378(9):840-51. https://doi.org/10.1056/NEJMra1708712

22. McKay KA, Tremlett H, Fisk JD, Zhang T, Patten SB Kastrukoff L, et al.; CIHR Team in the Epidemiology and Impact of Comorbidity on Multiple Sclerosis. Psychiatric comorbidity is associated with disability progression in multiple sclerosis. Neurology. 2018 Apr;90(15):e1316-23. https://doi.org/10.1212/WNL.0000000000005302 